\title{
Optimization of the Hot-Pressing Regime in the Production of Eco-Friendly Fibreboards Bonded with Hydrolysis Lignin
}

\author{
Ivo Valchev1, Yvailo Yordanov', Viktor Savov², Petar Antov² \\ ${ }^{1}$ Department of Pulp, Paper and Printing Arts, Faculty of Chemical Technologies, University of Chemical Technology and \\ Metallurgy, 1757 Sofia, 8 Kliment Ohridski blvd., Bulgaria \\ 2 Department of Mechanical Wood Technology, Faculty of Forest Industry, University of Forestry, 1797 Sofia, \\ 10 Kliment Ohridski blvd., Bulgaria \\ * Corresponding author, e-mail: victor_savov@ltu.bg
}

Received: 02 April 2021, Accepted: 27 May 2021, Published online: 15 September 2021

\begin{abstract}
This research was aimed at studying the potential of using residual lignin from acid hydrolysis as a binder in manufacturing ecofriendly, dry-process fibreboards. For that purpose, a modification of the adhesive system and hot-pressing regime was conducted. The adhesive system applied was composed of $2 \%$ phenol-formaldehyde (PF) resin and $10 \%$ hydrolysis lignin (based on the dry fibres). The PF resin does not only act as a binder but generally contributes to the even distribution and good retention of the main binder - hydrolysis lignin. A specific hot-pressing cycle was used. In the first stage, the pressure was $1.0 \mathrm{MPa}$, followed by an increased pressure of 4.0 MPa, and subsequent cooling. The purpose of the initial lower pressure was softening the lignin and reduction of the material moisture content. The effect of the second stage of hot-pressing on the properties of eco-friendly fibreboards was investigated. It was determined that the fibreboards produced with $2 \%$ PF resin and $10 \%$ hydrolysis lignin have similar physical and mechanical properties to those of the control panels, produced with $10 \%$ PF resin at a standard hot-pressing cycle. The findings of this work demonstrate that residual hydrolysis lignin can be effectively utilized as a binder in the production of eco-friendly, dry-process fibreboards with acceptable physical and mechanical properties.
\end{abstract}

Keywords

wood-based panels, eco-friendly, dry-process fibreboards, hydrolysis lignin, hot-pressing

\section{Introduction}

The development of the wood-based panel industry, related mainly to the mass introduction of continuous presses [1-3] and modification of the adhesive systems [4-8], led to the reduction of press factor from $10 \div 15 \mathrm{~s} \cdot \mathrm{mm}^{-1}$ to $4 \div 8 \mathrm{~s} \cdot \mathrm{mm}^{-1}[8,9]$. This reflects in increased productivity of the plants and enlarged production quantities, which in 2019 reached 357.6547 million $\mathrm{m}^{3}$ [10]. However, the issues associated with the environmental and human-health related impact of woodbased panels, mainly connected with the hazardous emission of free formaldehyde and other volatile organic compounds (VOCs) from the finished wood-based panels, still remain relevant [11-16]. At present, the woodbased plants aim to produce panels with formaldehyde emission class E1 ( $\leq 8 \mathrm{mg} / 100 \mathrm{~g})$. In addition, specialized formaldehyde catchers (scavengers), such as urea, amino groups, sodium metabisulfite, ammonium bisulfite or natural, bio-based formaldehyde scavengers, such as tannin powder, wheat or bark flours, etc., are often used to reduce formaldehyde emission [17, 18]. However, the panels from the E0 emission class are usually characterised by an increased production costs, hence, the industrial and scientific interest is directed at sustainable production of wood-based panels having a close-to-zero formaldehyde content, reaching E0 and super E0 classes, i.e. formaldehyde emissions equivalent to the natural wood levels $[19,20]$. The use of natural, bio-based adhesives as partial or complete substitutes of the traditional thermosetting resins is a perspective approach to achieve this goal [21-29]. The use of natural binders has another environmental effect, namely the utilization of residual natural resources from other industries [30-39].

Lignin is a polyaromatic macromolecule acting as the natural binder in wood [40-42]. It is also the second most 
abundant organic polymer in the world, surpassed only by cellulose $[43,44]$. At present, lignin is regarded as a waste or side-product from the pulp and paper industry as well as from biomass hydrolysis to bioethanol and other chemical products $[45,46]$, with an estimated annual production of approximately 100 million tons worldwide [47].

Currently, the main industrial practice is to use this valuable natural resource for heat and energy purposes [48-51] and less than $2 \%$ is utilized in valued-added applications [47], such as dispersants, reinforcement materials, and adhesives. The main difficulty in using lignin as a binder in wood-based panels is its introduction, retention and activation [52-54]. At present, a solution to this problem is sought mainly by modification of lignin $[55,56]$, including its enzymatic treatment [57]. Lignin contains different functional groups, i.e., methoxyl, hydroxyl, and carbonyl groups, which allow its chemical modification, applied mostly to increase its reactivity. Significant progress has been made in replacing phenol in phenol-formaldehyde resins [58-60]. All these modifications lead to increased costs of lignin-based adhesives which makes them difficult to apply in industrial conditions. Although the most common residual product is Kraft lignin, obtained by the Kraft process [61], hydrolysis lignin, derived by enzymatic hydrolysis process, contains a certain amount of cellulose. Cellulose in hydrolysis lignin increases the contact areas between lignin and wood fibres, which leads to the formation of additional hydrogen and other bonds [62-65]. The aim of the present study was to fabricate eco-friendly dry-process fibreboards using hydrolysis lignin as a main binder by modifying the adhesive system and optimising the hot-pressing regime, without any modifications of the lignin.

\section{Materials and methods \\ 2.1 Materials}

The pulp used in this research was provided by Welde Bulgaria AD (Troyan, Bulgaria). It was produced by the Asplund method with Defibrator L46 refiner (Valmet, Stockholm, Sweden), and composed of the following species: $60 \%$ beech (Fagus sylvatica L.), $20 \%$ Turkish oak (Quercus cerris L.) and $20 \%$ white poplar (Populus alba L.). The initial moisture content of the fibres was $11 \%$. Technical hydrolysis lignin was used as a binder. The lignin was obtained from the high temperature diluted sulphuric acid hydrolysis of sawdust and softwood and hardwood chips to sugars, which were further subjected to yeast fodder production.
Chemical analyses of technical hydrolysis lignin were carried out according to the following methods: cellulose [66]; lignin [67], ash [68]. The analysis of C, N, S and $\mathrm{H}$ was performed using Elemental Analyzer Euro EA 3000. The data are presented in Table 1.

\subsection{Preliminary results}

Previous research on the subject has shown that lignin is not appropriate to be added in a dry state $[69,70]$. In this state, it is not activated successfully and has to be used in larger quantities, which leads to sedimentation of the underside of the panels and significant deterioration of their appearance and properties of the fibreboards (Fig. 1). Therefore, hydrolysis lignin should be imported in the form of a suspension.

A study, in which hydrolysis lignin in the form of suspension was used, without an auxiliary binder, was carried out. In this case, an uneven distribution of lignin was found and hence a significant variation in the properties of the panels, Fig. 2. This led to the conclusion that an auxiliary binder should be used to retain lignin before its softening, plasticization and before forming stable bonds between lignin and wood fibres.

\subsection{Experimental plan}

Phenol-formaldehyde (PF) resin was used as an auxiliary binder. This type of resin was chosen because of its

Table 1 Characteristics of the technical hydrolysis lignin from the diluted sulphuric acid hydrolysis plant

\begin{tabular}{ccccccc}
\hline Lignin, \% & Cellulose, \% & $\begin{array}{c}\text { Ash } \\
\text { content, } \%\end{array}$ & C, \% & S, \% & H, \% & N, \% \\
\hline 72.6 & 25.5 & 2.8 & 55.54 & 0.74 & 7.10 & 0.26 \\
\hline
\end{tabular}

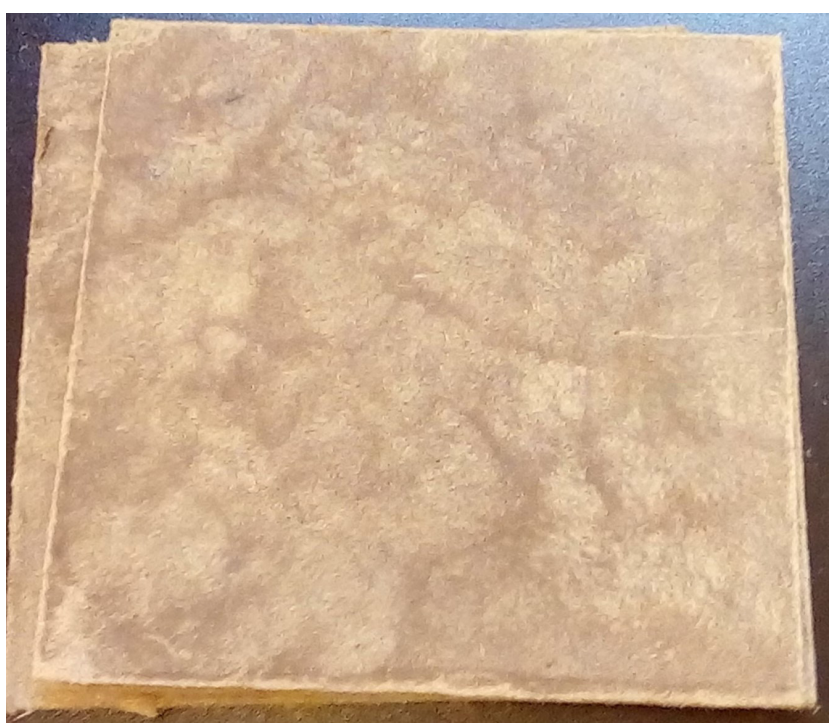

Fig. 1 Fibreboards with hydrolysis lignin added in a dry state. 


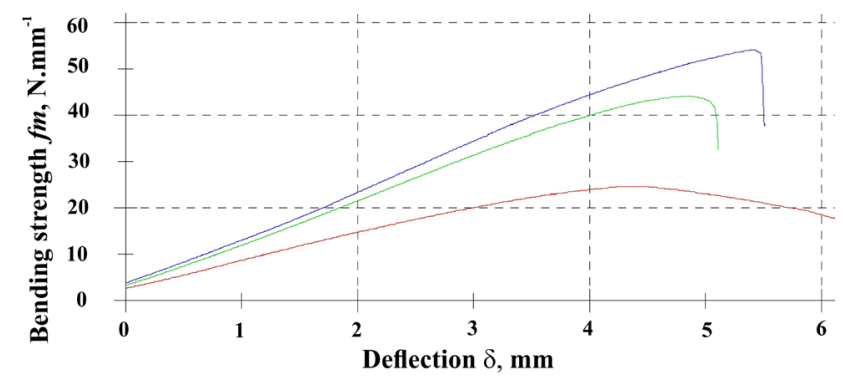

Fig. 2 Deformation behaviour under bending load of test samples from fibreboard with hydrolysis lignin without the use of an auxiliary binder.

significantly better compatibility with lignin [71-74], better adhesion properties and resistance to higher temperatures compared to urea-formaldehyde (UF) resin [75-77]. The adhesive formulation was comprised of $2 \% \mathrm{PF}$ resin (48.0\% dry solids content, viscosity $364 \mathrm{mPa} \mathrm{s}$, $\mathrm{pH}$ 6.6, brix 72.7) manufactured by Dynea, Romania, and $10 \%$ technical hydrolysis lignin as the main binder, based on the dry fibres. This percentage of lignin was chosen based on the previous research in the field which has shown that the most significant improvement in the properties of fibreboards is observed when the lignin content is increased to $10 \%$ [78]. The lignin was fractionated and only the fraction below $100 \mu \mathrm{m}$ was used.

The adhesive system, composed of hydrolysis lignin and PF resin, was introduced in the pulp at a concentration of $30 \%$. The introduction of the binders was carried out using a high-speed $\left(850 \mathrm{~min}^{-1}\right.$ ) laboratory blender with needle-shaped blades. The adhesive composition was injected through a nozzle with a diameter of $1.5 \mathrm{~mm}$, at a pressure of $0.4 \mathrm{MPa}$. Hot pressing was performed in a laboratory press Servitec - Polystat 200 T (Wustermark, Germany).

The produced panels had dimensions of $200 \times 200 \mathrm{~mm}$ at a thickness of $4 \mathrm{~mm}$ and a target density of $850 \mathrm{~kg} \cdot \mathrm{m}^{-3}$. The panels were manufactured at a hot-pressing temperature of $200{ }^{\circ} \mathrm{C}$. The press temperature was chosen based on the results of previous studies, which confirmed the improvement of the fibreboard properties with increasing temperature to this range $[79,80]$.

The panels with hydrolysis lignin were produced using a modified hot-pressing cycle: pressure in the first stage was 1.0 $\mathrm{MPa}$ (low pressure), pressure in the second stage was 4.0 MPa (high pressure) and subsequent cooling while maintaining the high pressure. The panels with hydrolysis lignin were produced using a modified hot-pressing cycle: pressure in the first stage was 1.0 MPa (low pressure), pressure in the second stage was 4.0 $\mathrm{MPa}$ (high pressure) and subsequent cooling while maintaining the high pressure. The value of the pressure in the first stage was chosen given the possibility of removing the vapour from the material, and in the second stage because of its densification. These pressure values are in line with those commonly used in the industry for that purpose [1,81].

The pressing time of the first stage was constant $-5 \mathrm{~min}$. This time was determined experimentally. For the conditions of the experiment (11\% moisture content of the fibres and $30 \%$ concentration of the adhesive system) in a shorter time, the vapour cannot be separated from the material, as a result of which combustion and hydrolysis occur in the components of the panels.

The press factor of the second stage varied as follows:

- Panel type A - $7.5 \mathrm{~s} \cdot \mathrm{mm}^{-1}$ (pressing time of $30 \mathrm{~s}$ ),

- Panel type B - $15 \mathrm{~s} \cdot \mathrm{mm}^{-1}$ (pressing time of $60 \mathrm{~s}$ ),

- Panel type $\mathrm{C}-22.5 \mathrm{~s} \cdot \mathrm{mm}^{-1}$ (pressing time of $90 \mathrm{~s}$ ),

- Panel type D - $30 \mathrm{~s} \cdot \mathrm{mm}^{-1}$ (pressing time of $120 \mathrm{~s}$ ) and

- Panel type E - $90 \mathrm{~s} \cdot \mathrm{mm}^{-1}$ (pressing time of $360 \mathrm{~s}$ ).

The purpose of this modified cycle was to plasticize and soften the lignin during the first low-pressure stage. Similar studies have shown that the plasticization of lignin leads to significantly better properties of the fibreboards [82]. Another modification of the pressing regime, namely cooling at the end of the hot-pressing, was applied. The cooling was aimed at converting the lignin, which has already formed bonds with the fibres, to a solid state. The cooling time was 3 minutes (until the temperature reached values below $100{ }^{\circ} \mathrm{C}$ ). Reference panels, with $10 \%$ PF resin (REF 10) and a standard hot-pressing cycle were also produced - the first stage 4.0 $\mathrm{MPa}$; second stage 1.2 $\mathrm{MPa}$; third stage $0.6 \mathrm{MPa}$ and fourth stage $1.5 \mathrm{MPa}$. Control panels were produced at a press-factor of $30 \mathrm{~s} \cdot \mathrm{mm}^{-1}$. The press temperature used was $200{ }^{\circ} \mathrm{C}$. Following the hot pressing, the fibreboards were conditioned for seven days at $20 \pm 2{ }^{\circ} \mathrm{C}$ and $65 \%$ relative humidity.

From each type of boards were produced three panels. The physical and mechanical properties of the fibreboards were determined by testing 8 test samples for each property. The properties of the panels were determined according to the methods defined in the EN [83-85]. A Zwick / Roell Z010, Ulm, Germany universal testing machine was used for the determination of the mechanical properties of the panels.

\section{Results and analyses}

The laboratory-produced panels are presented in Fig. 3. The density of the panels is presented in Table 2 .

The manufactured panels had a density rather close to the targeted value of $850 \mathrm{~kg} \cdot \mathrm{m}^{-3}$. The highest density was determined for Panel Type $\mathrm{D}-876 \mathrm{~kg} \cdot \mathrm{m}^{-3}$, and the lowest 


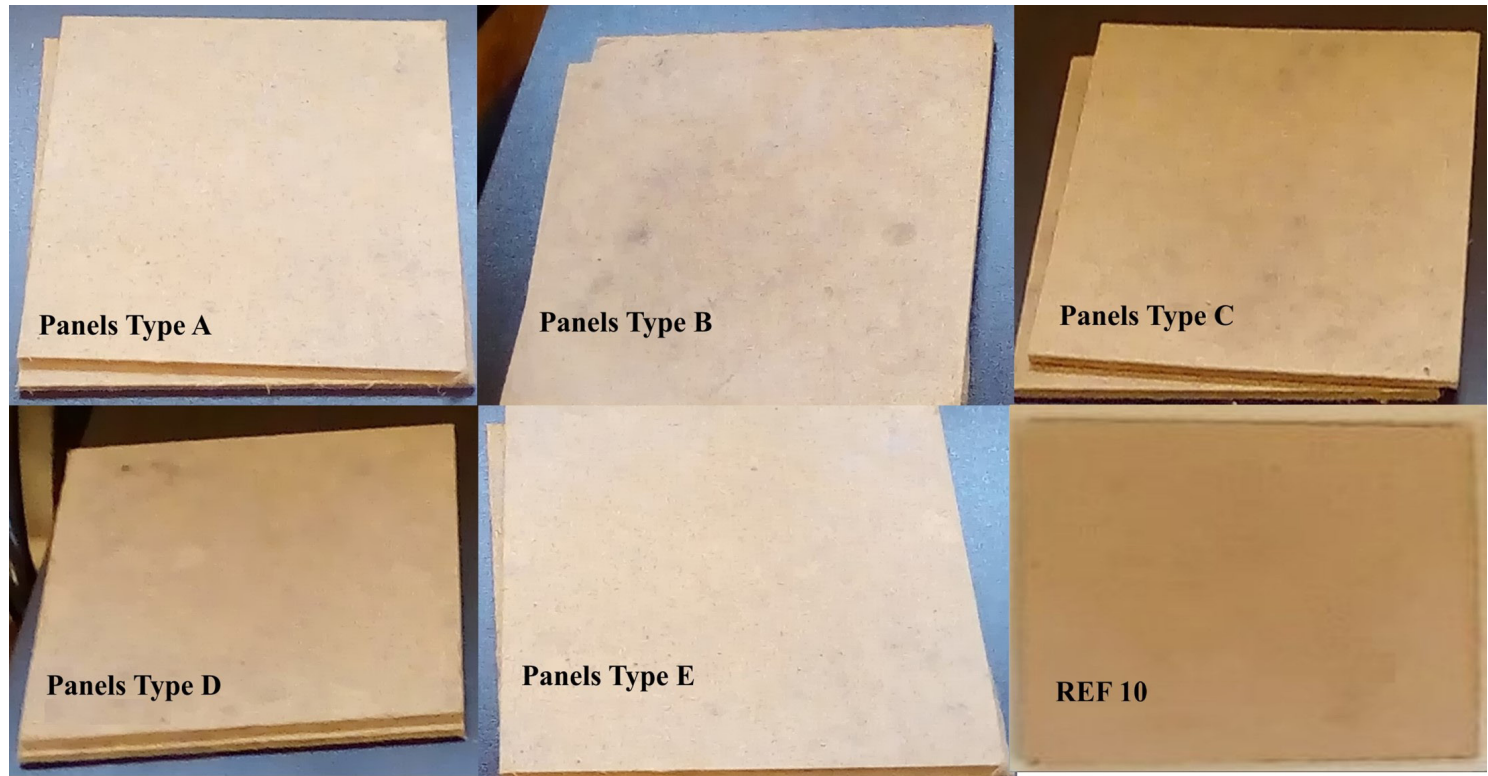

Fig. 3 Eco-friendly dry-process fibreboard panels with an adhesive system comprised of $10 \%$ hydrolyses lignin and $2 \%$ PF resin. Type A - second stage press factor $7.5 \mathrm{~s} \cdot \mathrm{mm}^{-1}$; Type B - second stage press factor $15 \mathrm{~s} \cdot \mathrm{mm}^{-1}$; Type C - second stage press factor $22.5 \mathrm{~s} \cdot \mathrm{mm}^{-1}$; Type D - second stage press factor $30 \mathrm{~s} \cdot \mathrm{mm}^{-1}$; Type E - second stage press factor $90 \mathrm{~s} \cdot \mathrm{mm}^{-1} ; \mathrm{REF} 10-10 \% \mathrm{PF}$ resin.

Table 2 Density of the eco-friendly dry-process fibreboard panels with an adhesive system comprised of $10 \%$ hydrolysis lignin and $2 \% \mathrm{PF}$ resin

\begin{tabular}{lcccccc}
\hline Panel Type & Type A & Type B & Type C & Type D & Type E & REF 10 \\
\hline $\begin{array}{l}\text { Density } \rho, \\
\text { kg.m }{ }^{-3}\end{array}$ & $861 \pm 20$ & $865 \pm 17$ & $867 \pm 15$ & $876 \pm 22$ & $854 \pm 12$ & $871 \pm 6$ \\
\hline
\end{tabular}

for Panel Type E - $854 \mathrm{~kg} \cdot \mathrm{m}^{-3}$. The difference between these two density values was $2.58 \%$, i.e. significantly below the permissible statistical error of $5 \%$. The $p$-value, after conducting a t-test for the densities of these two panels is 0.258 (above 0.05), i.e. there was no statistical difference between the density mean values of the panels. Thus, it can be concluded that the density of the panels did not have a significant effect on the other physical and mechanical properties of the panels, and the deviation of the properties will result from altering the hot-pressing regime.

The results for the water absorption (WA) of the panels are presented in Fig. 4.

WA of the panels with an adhesive system of $2 \% \mathrm{PF}$ resin and $10 \%$ hydrolysis lignin varied from $75.34 \%$ to $64.29 \%$. The main decrease (improvement) in the value of the property by 1.08 times was determined when the second stage press factor was increased from 7.5 to $15 \mathrm{~s} \cdot \mathrm{mm}^{-1}$. The next improvement resulted from the increase of press factor from 22.5 to $30 \mathrm{~s} \cdot \mathrm{mm}^{-1}$. In that case, the WA of the panels was improved by 1.07 times. However, the conducted t-tests showed that the only statistical difference was between the WA of the panels produced with a press factor of $7.5 \mathrm{~s} \cdot \mathrm{mm}^{-1}$ and those at $15 \mathrm{~s} \cdot \mathrm{mm}^{-1}$. The $p$-value

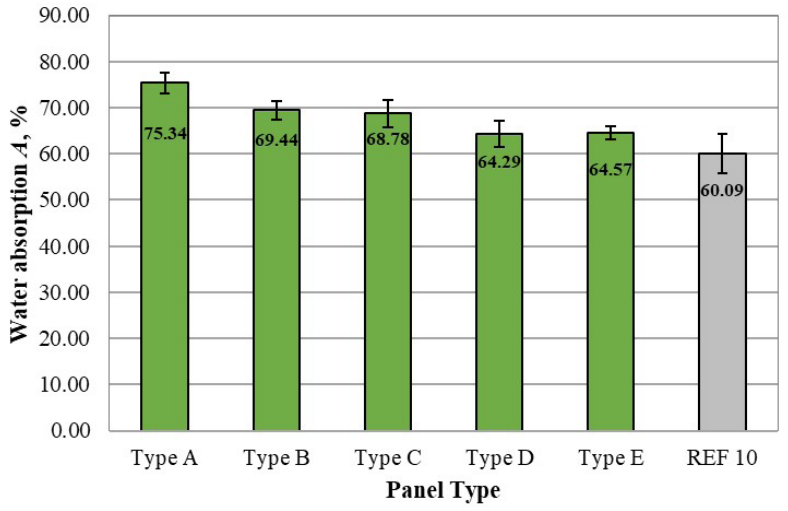

Fig. 4 Water absorption (24 h) of eco-friendly dry-process fibreboards bonded with $10 \%$ hydrolysis lignin and $2 \%$ PF resin.

Type A - second stage press factor $7.5 \mathrm{~s} \cdot \mathrm{mm}^{-1}$; Type B - second stage press factor $15 \mathrm{~s} \cdot \mathrm{mm}^{-1}$; Type $\mathrm{C}$ - second stage press factor $22.5 \mathrm{~s} \cdot \mathrm{mm}^{-1}$;

Type D - second stage press factor $30 \mathrm{~s} \cdot \mathrm{mm}^{-1}$; Type E - second stage press factor $90 \mathrm{~s} \cdot \mathrm{mm}^{-1}$; REF $10-10 \%$ PF resin.

from this t-test was 0.009 . This revealed that regarding the WA it is not justified to extend the second stage press factor above $15 \mathrm{~s} \cdot \mathrm{mm}^{-1}$.

A graphical representation of the thickness swelling (TS) values (24 h) of the laboratory-produced panels is presented in Fig. 5.

The TS of the panels produced with hydrolysis lignin as the main binder varied from $34.37 \%$ to $27.53 \%$. Therefore, the increase of the second stage press factor led to an improvement of that property by 1.25 times. The main improvement was determined at the increase of 


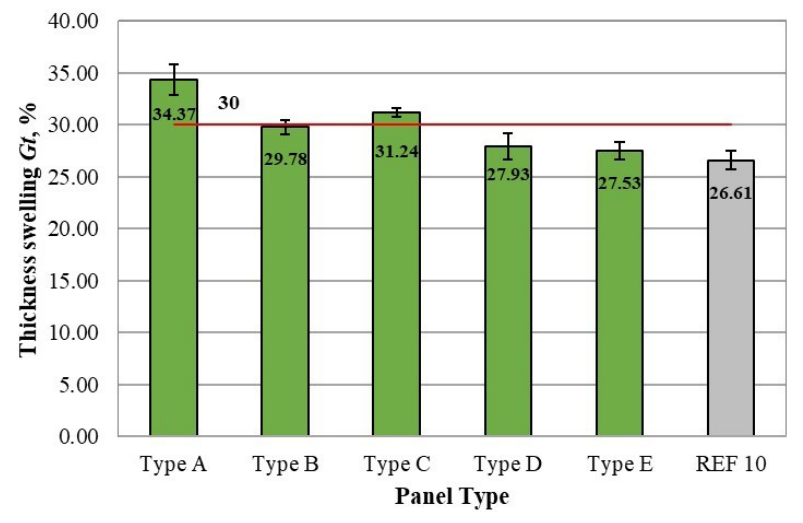

Fig. 5 Thickness swelling ( $24 \mathrm{~h}$ ) of eco-friendly dry-process fibreboards bonded with $10 \%$ hydrolysis lignin and $2 \% \mathrm{PF}$ resin (the red line represents the EN 622-5 standard requirement for loadbearing boards for use in humid conditions). Type A - second stage press factor $7.5 \mathrm{~s} \cdot \mathrm{mm}^{-1}$; Type $\mathrm{B}$ - second stage press factor $15 \mathrm{~s} \cdot \mathrm{mm}^{-1}$; Type $\mathrm{C}$ - second stage press factor $22.5 \mathrm{~s} \cdot \mathrm{mm}^{-1}$; Type D - second stage press factor $30 \mathrm{~s} \cdot \mathrm{mm}^{-1}$; Type E - second stage press factor $90 \mathrm{~s} \cdot \mathrm{mm}^{-1}$; REF $10-10 \%$ PF resin.

press factor from $7.5 \mathrm{~s} \cdot \mathrm{mm}^{-1}$ to $15 \mathrm{~s} \cdot \mathrm{mm}^{-1}$. In this case, the improvement was by 1.15 times.

With t-tests, it was established that there was no statistical difference between the thickness swelling of the panels produced at press factors 15 and $22.5 \mathrm{~s} \cdot \mathrm{mm}^{-1}$ ( $p$-value is 0.17). A significant improvement in the TS was observed when the second stage press factor was increased from 22.5 to $30 \mathrm{~s} \cdot \mathrm{mm}^{-1}$. The improvement is 1.12 times. Again, after a t-test, it was found that there was no statistical difference between the values for swelling in the thickness of the panels at a press factor of 30 and $90 \mathrm{~s} \cdot \mathrm{mm}^{-1}$ ( $p$-value is 0.20 ). All this leads to the conclusion that for the improvement of the TS values of eco-friendly fibreboards bonded with hydrolysis lignin, it is not justified the press factor of the second stage to be above $30 \mathrm{~s} \cdot \mathrm{mm}^{-1}$.

Markedly, the panels manufactured with $2 \%$ PF resin and $10 \%$ hydrolysis lignin at modified hot-pressing cycle and second stage press factor of $30 \mathrm{~s} \cdot \mathrm{mm}^{-1}$, had TS values similar to that of the panels with $10 \%$ PF resin, produced at standard hot-pressing cycle. The performed t-test showed that there was no statistical difference between these two types of panels - the $p$-value is 0.27 .

All panels with hydrolysis lignin as the main binder met the standard requirements for TS for load-bearing boards and use in dry conditions. Panels with a press factor of $15 \mathrm{~s} \cdot \mathrm{mm}^{-1}$ met the most stringent requirements for TS, namely for load-bearing applications for use in humid conditions [86].

The results for the modulus of elasticity (MOE) of the panels are given in Fig. 6.

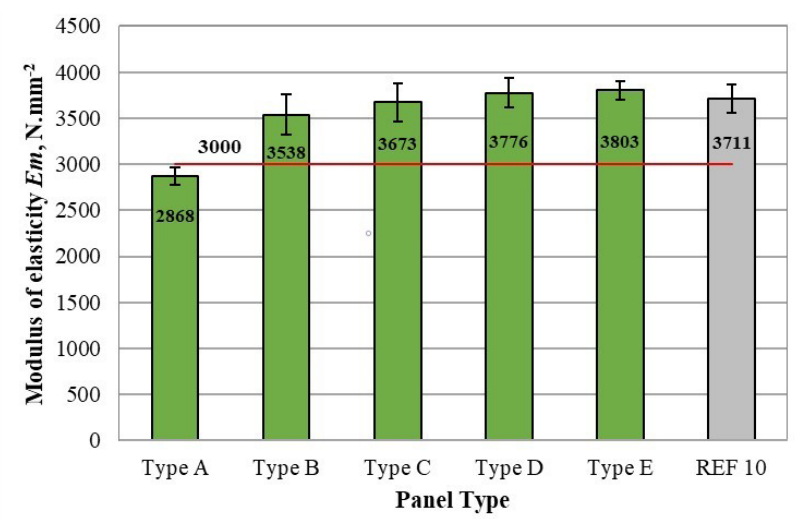

Fig. 6 Modulus of elasticity (MOE) of eco-friendly dry-process fibreboards bonded with $10 \%$ hydrolysis lignin and $2 \%$ PF resin (the red line represents the EN 622-5 standard requirement for load-bearing applications for use in humid conditions). Type $\mathrm{A}-$ second stage press factor $7.5 \mathrm{~s} \cdot \mathrm{mm}^{-1}$; Type $\mathrm{B}$ - second stage press factor $15 \mathrm{~s} \cdot \mathrm{mm}^{-1}$; Type $\mathrm{C}$ - second stage press factor $22.5 \mathrm{~s} \cdot \mathrm{mm}^{-1}$; Type $\mathrm{D}$ - second stage press factor $30 \mathrm{~s} \cdot \mathrm{mm}^{-1}$; Type $\mathrm{E}-$ second stage press factor $90 \mathrm{~s} \cdot \mathrm{mm}^{-1}$; REF $10-10 \%$ PF resin.

The laboratory-produced fibreboards, bonded with hydrolysis lignin exhibited MOE values, ranging from 2868 to $3803 \mathrm{~N} \cdot \mathrm{mm}^{-2}$. That is, the increase in the second stage press factor above $7.5 \mathrm{~s} \cdot \mathrm{mm}^{-1}$, resulted in improvement of the property by $32.60 \%$. It should be noted that the only statistical difference between the properties for the individual panels was determined for the fibreboards produced with a press factor of $7.5 \mathrm{~s} \cdot \mathrm{mm}^{-1}$ and those with a press factor of $15 \mathrm{~s} \cdot \mathrm{mm}^{-1}$ ( $p$-value is 0.01 ). Further increase in the press factor did not lead to a significant improvement of the MOE values. After performed the t-test, it was found that there was no statistical difference between the MOE of the panels produced at a press factor of $15 \mathrm{~s} \cdot \mathrm{mm}^{-1}$ and the reference panels with $10 \% \mathrm{PF}$ resin ( $p$-value is 0.42 ). Therefore, eco-friendly fibreboards with MOE values, similar to those of fibreboards produced with $10 \% \mathrm{PF}$ resin, can be manufactured by using an adhesive composition of only $2 \%$ PF resin and $10 \%$ hydrolysis lignin, with a second stage press factor of $15 \mathrm{~s} \cdot \mathrm{mm}^{-1}$.

All laboratory-fabricated panels bonded with hydrolysis lignin met the requirements regarding the MOE of fibreboards for general purpose and use in humid conditions. Fibreboards produced at the second stage press factor of $15 \mathrm{~s} \cdot \mathrm{mm}^{-1}$ met the strictest requirements for the property for load-bearing boards and use in humid conditions [86].

The results for the bending strength (MOR) of the panels are presented in Fig. 7.

For the experimental conditions, the MOR values of eco-friendly fibreboards bonded with $10 \%$ hydrolysis lignin varied from $31.24 \mathrm{~N} \cdot \mathrm{mm}^{-2}$ to $43.69 \mathrm{~N} \cdot \mathrm{mm}^{-2}$. That is, 


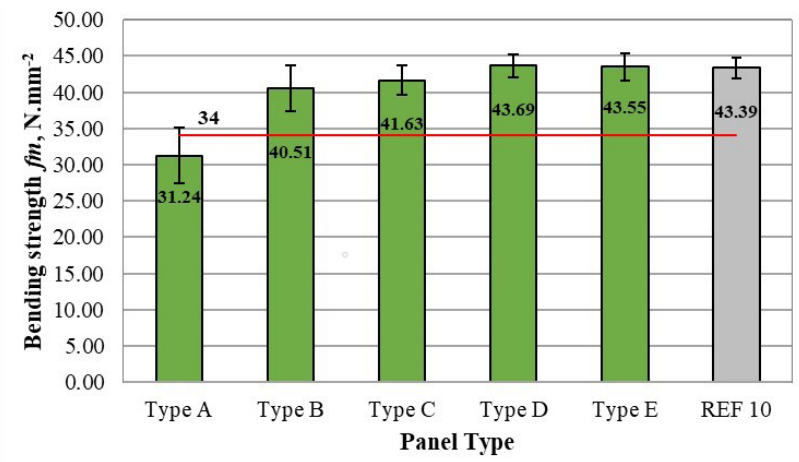

Fig. 7 Bending strength (MOR) of eco-friendly dry-process fibreboards bonded with $10 \%$ hydrolysis lignin and $2 \% \mathrm{PF}$ resin (the red line represents the EN 622-5 standard requirement for load-bearing applications for use in humid conditions). Type A - second stage press factor $7.5 \mathrm{~s} \cdot \mathrm{mm}^{-1}$; Type $\mathrm{B}$ - second stage press factor $15 \mathrm{~s} \cdot \mathrm{mm}^{-1}$; Type $\mathrm{C}$ - second stage press factor $22.5 \mathrm{~s} \cdot \mathrm{mm}^{-1}$; Type $\mathrm{D}$ - second stage press factor $30 \mathrm{~s} \cdot \mathrm{mm}^{-1}$; Type $\mathrm{E}-$ second stage press factor $90 \mathrm{~s} \cdot \mathrm{mm}^{-1}$; REF $10-10 \%$ PF resin.

the improvement in this property was by $39.85 \%$. It should be emphasized that the only statistical difference was in the panels produced at the second stage press factor of $7.5 \mathrm{~s} \cdot \mathrm{mm}^{-1}$ and those at $15 \mathrm{~s} \cdot \mathrm{mm}^{-1}$ ( $p$-value is 0.005$)$. That is, it was confirmed that given the mechanical properties of the panels, the second stage press factor of $7.5 \mathrm{~s} \cdot \mathrm{mm}^{-1}$ is insufficient for the formation of stable bonds between the hydrolysis lignin and the wood fibres. However, at a press factor of $15 \mathrm{~s} \cdot \mathrm{mm}^{-1}$, panels with very good mechanical properties could be produced, and a subsequent increase in the second stage press factor did not lead to further improvement. This is why the optimal second stage press factor for the production of eco-friendly fibreboards bonded with $10 \%$ hydrolysis lignin as the main binder was $15 \mathrm{~s} \cdot \mathrm{mm}^{-1}$. The performed t-test showed that there was no statistical difference between the MOR values of the panels produced at the second stage press factor of $15 \mathrm{~s} \cdot \mathrm{mm}^{-1}$ and the reference panels with $10 \% \mathrm{PF}$ resin ( $p$-value is 0.187 ), i.e. the eco-friendly fibreboards with $2 \%$ PF resin and $10 \%$ hydrolysis lignin, produced at a second stage press factor of $15 \mathrm{~s} \cdot \mathrm{mm}^{-1}$ had a MOR values, quite comparable to those of the panels with $10 \%$ PF resin.

All eco-friendly fibreboards bonded with $10 \%$ hydrolysis lignin met the requirements for general-purpose fibreboards for use in humid conditions. With the exception of the panel produced at the second stage press factor of $7.5 \mathrm{~s} \cdot \mathrm{mm}^{-1}$, all other eco-friendly panels met the strictest requirements for the property - for load-bearing boards and use in humid conditions [86].

The obtained results for eco-friendly fibreboards manufactured with a modified adhesion system and press cycle were comparable and better than those reported in similar studies [69, 79, 80, 87]. The obtained eco-friendly fibreboards had a lower density and better properties than those obtained by Zhou et al. [79], and the lignin is not enzymatically modified. Compared with the study by Tupciauskas et al. [69], the obtained fibreboards had similar properties, but at a much lower density of $850 \mathrm{~kg} \cdot \mathrm{m}^{-3}$ versus $1300 \mathrm{~kg} \cdot \mathrm{m}^{-3}$, at a significantly lower lignin content of $10 \%$ versus $25 \%$. In addition, the hydrolysis lignin used in the present study did not impair the appearance of the panels. The results obtained are also comparable to those obtained by Theng et al. [80], but again at a lower density of fibreboards and lower lignin content than in the study by Nasir et al. [87].

\section{Conclusions}

In the present study, it was found that hydrolysis lignin can be successfully used as a binder with very good performance in the production of eco-friendly dry-process fibreboards. A solution is proposed to eliminate the main disadvantages of hydrolysis lignin as a binder - its introduction and retention in the fibres and its activation in the process of hot-pressing. The results of the study show that the hydrolysis lignin is activated by modifying the hot-pressing cycle, without the need to apply additional modifications or treatment with enzymes. The modifications of lignin proposed in previous studies significantly increase costs and make it difficult to apply in industrial conditions. The optimization of the hot-pressing cycle is easily feasible in industrial conditions when using continuous presses, which have autonomous heating of the individual sections. That is, cooling will not lead to additional costs for reheating, which was typical of older technologies using multi-story presses.

The implemented modification of the adhesive system overcomes another major disadvantage of hydrolysis lignin, namely its retention in the pulp. The small amount of PF resin used (comparable to that used in the wet-process) performs precisely the role of lignin retention and partial auxiliary function as a binder.

The study showed that to achieve the most stringent requirements for mechanical properties of eco-friendly panels, it is not necessary to extend the second stage press factor above $15 \mathrm{~s} \cdot \mathrm{mm}^{-1}$, and above $30 \mathrm{~s} \cdot \mathrm{mm}^{-1}$, regarding the water-repellent properties. It is very promising that the requirements for general-purpose fibreboards (the most common type on the market) are achieved even with a second stage press factor of $7.5 \mathrm{~s} \cdot \mathrm{mm}^{-1}$. Future studies should 
be focused on the optimization of the first stage of the pressing regime and establishing the optimal moisture content of the fibre mat at which hydrolysis lignin is activated.

\section{Acknowledgement}

The project № КП-06-КОСТ/1, presented in this article is supported by Bulgarian National Science Fund.

\section{References}

[1] Anonym "Countypress Technology", Metso Paper, 21(4), pp. 10-14, 2005.

[2] Dieffenbacher "Wood-based panels", [online] Available at: https://dieffenbacher.com/en/wood-based-panels [Accessed: 09 March 2021]

[3] Siempelkamp "Siempelkamp plants for wood-based materials production", [online] Available at: https:/www.siempelkamp.com/ en/products-and-technologies/machine-and-plant-engineering/ wood-based-panel-plants/ [Accessed: 10 March 2021]

[4] Carvalho, L. H., Magalhães, F. D., João, F. "Formaldehyde Emissions from Wood-Based Panels - Testing Methods and Industrial Perspectives", In: Cheng, C. B., Ln, F. H. (eds.) Formaldehyde: Chemistry, Applications and Role in Polymerization, Nova Science Publishers, Inc., Hauppauge, NY, USA, 2012, pp. 73-107.

[5] Rowell, R. M. "Wood Composites", In: Handbook of Wood Chemistry and Wood Composites, CRC Press, Boca Raton, FL, USA, 2012, pp. 255-511. https://doi.org/10.1201/b12487-15

[6] Mantanis, G. I., Athanassiadou, E. T., Barbu, M. C., Wijnendaele, K. "Adhesive systems used in the European particleboard, MDF and OSB industries", Wood Material Science and Engineering, 13(2), pp. 104-116, 2017.

https://doi.org/10.1080/17480272.2017.1396622

[7] Sydor, M., Pałubicki, B. "Shape stability of chosen thin wood based panels after heating", Annals of WULS - SGGW, Forestry and Wood Technology, 106, pp. 85-89, 2019 https://doi.org/10.5604/01.3001.0013.7742

[8] Papadopoulos, A. N. "Advances in Wood Composites", Polymers, 12(1), Article number: 48, 2020. https://doi.org/10.3390/polym12010048

[9] Savov, V., Antov, P. "Engineering the Properties of Eco-Friendly Medium Density Fibreboards Bonded with Lignosulfonate Adhesive", Drvna Industrija, 71(2), pp. 157-162, 2020. https://doi.org/10.5552/drvind.2020.1968

[10] Food and Agriculture Organization of the United Nations "Forestry Production and Trade", [online] Available at: http://www.fao.org/ faostat/en/\#data/FO [Accessed: 14 May 2021]

[11] Popović, M., Điporovic-Momčilović, M., Gavrilović-Grmuša, I. "New standards and regulations on formaldehyde emission from wood-based composite panels", Zastita Materijala, 61(2), pp. 152-160, 2020. https://doi.org/10.5937/zasmat2002152P

[12] Dunky, M. "Wood Adhesives Based on Natural Resources: A Critical Review Part III. Tannin- and Lignin-Based Adhesives", Reviews of Adhesion and Adhesives, 8(4), pp. 379-525, 2020. https://doi.org/10.7569/RAA-2020-097313
This publication is also the result of the implementation of the project No. НИС-Б-1145/04.2021 "Development, Properties and Application of Eco-Friendly Wood-Based Composites" carried out at the University of Forestry, Sofia, Bulgaria.

[13] Tudor, E. M., Barbu, M. C., Petutschnigg, A., Réh, R., Krišták, L. "Analysis of Larch-Bark Capacity for Formaldehyde Removal in Wood Adhesives", International Journal of Environmental Research and Public Health, 17(3), Article number: 764, 2020. https://doi.org/10.3390/ijerph17030764

[14] Réh, R., Krišták, L', Sedliačik, J., Bekhta, P., Božiková, M., Kunecová, D., Vozárová, V., Tudor, E. M., Antov, P., Savov, V. "Utilization of Birch Bark as an Eco-Friendly Filler in UreaFormaldehyde Adhesives for Plywood Manufacturing", Polymers, 13(4), Article number: 511, 2021. https://doi.org/10.3390/polym13040511

[15] Bekhta, P., Sedliačik, J., Noshchenko, G., Kačík, F., Bekhta, N. "Characteristics of beech bark and its effect on properties of UF adhesive and on bonding strength and formaldehyde emission of plywood panels", European Journal of Wood and Wood Products, 79(2), pp. 423-433, 2021. https://doi.org/10.1007/s00107-020-01632-8

[16] Papadopoulos, A. N. "Advances in Wood Composites III”, Polymers, 13(1), Article number: 163, 2021. https://doi.org/10.3390/polym13010163

[17] Costa, N. A., Pereira, J., Ferra, J., Cruz, P., Martins, J., Magalhāes, F. D., Mendes, A., Carvalho, L. H. "Scavengers for achieving zero formaldehyde emission of wood-based panels", Wood Science and Technology, 47(6), pp. 1261-1272, 2013. https://doi.org/10.1007/s00226-013-0573-4

[18] Antov, P., Savov, V., Neykov, N. "Reduction of Formaldehyde Emission from Engineered Wood Panels by Formaldehyde Scavengers - A Review", In: 13th International Scientific Conference WoodEMA 2020 and 31st International Scientific Conference ICWST 2020 Sustainability of Forest-Based Industries in the Global Economy, Vinkovci, Croatia, 2020, pp. 7-11.

[19] Wedaïna, A. G., Pizzi, A., Nzie, W., Danwe, R., Konai, N., Amirou, S., Segovia, C., Kueny, R. "Performance of Unidirectional Biocomposite Developed with Piptadeniastrum Africanum Tannin Resin and Urena Lobata Fibers as Reinforcement", Journal of Renewable Materials, 9(3), pp. 477-493, 2021. https://doi.org/10.32604/jrm.2021.012782

[20] Tisserat, B. H., Eller, F. J., Mankowski, M. E. "Properties of Composite Wood Panels Fabricated from Eastern Redcedar Employing Various Bio-based Green Adhesives", BioResources, 14(3), pp. 6666-6685, 2019.

[21] Papadopoulou, E. "Adhesives from renewable resources for binding wood-based panels", Journal of Environmental Protection and Ecology, 10, pp. 1128-1136, 2009. 
[22] Hemmilä, V., Adamopoulos, S., Karlsson, O., Kumar, A. "Development of sustainable bio-adhesives for engineered wood panels - A Review", Royal Society of Chemistry Advances, 7(61), pp. 38604-38630, 2017. https://doi.org/10.1039/c7ra06598a

[23] Ferdosian, F., Pan, Z., Gao, G., Zhao, B. "Bio-Based Adhesives and Evaluation for Wood Composites Application", Polymers, 9(2), Article number: 70, 2017. https://doi.org/10.3390/polym9020070

[24] Chang, B. P., Mohanty, A. K., Misra, M. "Studies on durability of sustainable biobased composites: a review", Royal Society of Chemistry Advances, 10(31), pp. 17955-17999, 2020. https://doi.org/10.1039/C9RA09554C

[25] Ghahri, S., Pizzi, A. "Improving soy-based adhesives for wood particleboard by tannins addition", Wood Science and Technology, 52(1), pp. 261-279, 2018. https://doi.org/10.1007/s00226-017-0957-y

[26] Ghahri, S., Mohebby, B., Pizzi, A., Mirshokraie, A., Mansouri, H. R. "Improving Water Resistance of Soy-Based Adhesives by Vegetable Tannins", Journal of Polymers and the Environment, 26(5), pp. 1881-1890, 2018. https://doi.org/10.1007/s10924-017-1090-6

[27] Antov, P., Savov, V., Neykov, N. "Sustainable Bio-based Adhesives for Eco-Friendly Wood Composites. A Review", Wood Research, 65(1), pp. 51-62, 2020. https://doi.org/10.37763/wr.1336-4561/65.01.051062

[28] Antov, P., Krišták, L', Réh, R., Savov, V., Papadopoulos, A. N. "Eco-Friendly Fiberboard Panels from Recycled Fibres Bonded with Calcium Lignosulfonate", Polymers, 13(4), Article number: 639,2021 https://doi.org/10.3390/polym13040639

[29] Ghahri, S., Chen, X., Pizzi, A., Hajihassani, R., Papadopoulos, A. N. "Natural Tannins as New Cross-Linking Materials for Soy-Based Adhesives", Polymers, 13(4), Article number: 595, 2021. https://doi.org/10.3390/polym13040595

[30] Makovicka Osvaldova, L., Markova, I., Jochim, S., Bares, J. "Experimental Study of Straw-Based Eco-Panel Using a Small Ignition Initiator", Polymers, 13(8), Article number: 1344, 2021. https://doi.org/10.3390/polym13081344

[31] Gopalakrishnan, K., Kim, S., Ceylan, H. "Lignin Recovery and Utilization", In: Khanal, S. K., Surampalli, R. Y., Zhang, T. C., Lamsal, B. P., Tyagi, R. D., Kao, C. M. (eds.) Bioenergy and Biofuel from Biowastes and Biomass, ASCE Press, Reston, VA, USA, 2010, pp. 247-274 https://doi.org/10.1061/9780784410899.ch12

[32] Căpraru, A. M., Creangă, Ș., Trinca, L. C., Borş, S. I., Ungureanu, E., Măluțan, T., Popa, I. V. "Valorization of lignin modified by hydroxymethylation to ensure birch veneer bioprotection", Cellulose Chemistry and Technology, 49(9-10), pp. 765-774, 2015.

[33] Falah, F., Lubis, M. A. R., Triastuti, T., Fatriasari, W., Sari, F. P. "Utilization of Lignin from the Waste of Bioethanol Production as a Mortar Additive", Journal Sylva Lestari, 8(3), pp. 326-339, 2020. https://doi.org/10.23960/js138326-339
[34] He, Q., Ziegler-Devin, I., Chrusciel, L., Obame, S. N., Hong, L., $\mathrm{Lu}, \mathrm{X} .$, Brosse, N. "Lignin-First Integrated Steam Explosion Process for Green Wood Adhesive Application", ACS Sustainable Chemistry and Engineering, 8(13), pp. 5380-5392, 2020. https://doi.org/10.1021/acssuschemeng.0c01065

[35] Ružiak, I., Igaz, R., Krišták, L., Réh, R., Mitterpach, J., Očkajová, A., Kučerka, M. "Influence of Urea-formaldehyde Adhesive Modification with Beech Bark on Chosen Properties of Plywood", BioResources, 12(2), pp. 3250-3264, 2017. https://doi.org/10.15376/biores.12.2.3250-3264

[36] Bekhta, P., Sedliačik, J., Kačík, F., Noshchenko, G., Kleinová, A. "Lignocellulosic waste fibers and their application as a component of urea-formaldehyde adhesive composition in the manufacture of plywood", European Journal of Wood and Wood Products, 77, pp. 495-508, 2019. https://doi.org/10.1007/s00107-019-01409-8

[37] Barbu, M. C., Montecuccoli, Z., Förg, J., Barbeck, U., Klímek, P., Petutschnigg, A., Tudor, E. M. "Potential of Brewer's Spent Grain as a Potential Replacement of Wood in pMDI, UF or MUF Bonded Particleboard", Polymers, 13(3), Article number: 319, 2021. https://doi.org/10.3390/polym13030319

[38] Khalaf, Y., El Hage, P., Mihajlova, J. D., Bergeret, A., Lacroix, P., El Hage, R. "Influence of agricultural fibers size on mechanical and insulating properties of innovative chitosan-based insulators", Construction and Building Materials, 287, Article number: 123071, 2021. https://doi.org/10.1016/j.conbuildmat.2021.123071

[39] Rammou, E., Mitani, A., Ntalos, G., Koutsianitis, D., Taghiyari, H. R., Papadopoulos, A. N. "The Potential Use of Seaweed (Posidonia oceanica) as an Alternative Lignocellulosic Raw Material for Wood Composites Manufacture", 11(1), Article number: 69, 2021. https://doi.org/10.3390/coatings11010069

[40] Sebio-Puñal, T., Naya, S., López-Beceiro, J., Tarrío-Saavedra, J., Artiaga, R. "Thermogravimetric analysis of wood, holocellulose, and lignin from five wood species", Journal of Thermal Analysis and Calorimetry, 109(3), pp. 1163-1167, 2012. https://doi.org/10.1007/s10973-011-2133-1

[41] Solihat, N. N., Sari, F. P., Falah, F., Ismayati, M., Lubis, M. A. R., Fatriasari, W., Santoso, E. B., Syafii, W. "Lignin as an Active Biomaterial: A Review", Jurnal Sylva Lestari, 9(1), pp. 1-22, 2021. https://doi.org/10.23960/js1191-22

[42] Saražin, J., Pizzi, A., Amirou, S., Schmiedl, D., Šernek, M. "Organosolv Lignin for Non-Isocyanate Based Polyurethanes (NIPU) as Wood Adhesive", Journal of Renewable Materials, 9(5), pp. 881-907, 2021. https://doi.org/10.32604/jrm.2021.015047

[43] Balakshin, M., Capanema, E. A., Zhu, X., Sulaeva, I., Potthast, A., Rosenau, T., Rojas, O. J. "Spruce milled wood lignin: linear, branched or cross-linked?", Green Chemistry, 22(13), pp. 3985-4001, 2020. https://doi.org/10.1039/D0GC00926A

[44] Iravani, S., Varma, R. S. "Greener synthesis of lignin nanoparticles and their applications", Green Chemistry, 22(3), pp. 612-636, 2020. https://doi.org/10.1039/c9gc02835H 
[45] Gothwal, R. K., Medicherla, K. M., Ghosh, P. "Synthesis of low cost adhesives from pulp \& paper industry waste", Journal of Scientific and Industrial Research, 69(5), pp. 390-395, 2010.

[46] Yoo, C. G., Ragauskas, A. J. "Opportunities and Challenges of Lignin Utilization", In: Yoo, C. G., Ragauskas, A. (eds.) Lignin Utilization Strategies: From Processing to Applications, ACS Symposium Series, American Chemical Society, Washington, DC, USA, 2021, pp. 1-12.

https://doi.org/10.1021/bk-2021-1377.ch001

[47] Bajwa, D. S., Pourhashem, G., Ullah, A. H., Bajwa, S. G. "A concise review of current lignin production, applications, products and their environmental impact", Industrial Crops and Products, 139, Article number: 111526, 2019.

https://doi.org/10.1016/j.indcrop.2019.111526

[48] Xiang, Z., Han, W., Deng, J., Zhu, W., Zhang, Y., Wang, H. "Photocatalytic Conversion of Lignin to Chemicals and Fuels", ChemSusChem, 13(17), Special Issue: Lignin Valorization: From Theory to Practice, pp. 4199-4213, 2020. https://doi.org/10.1002/cssc.202000601

[49] Wang, D., Lee, S. H., Han, S., Kim, J., Trang, N. V. T., Kim, K., Choi, E. G., Boonmongkolras, P., Lee, Y. W., Shin, B., Kim, Y. H., Park, C. B. "Lignin-fueled photoelectrochemical platform for light-driven redox biotransformation", Green Chemistry, 22(15), pp. 5151-5160, 2020. https://doi.org/10.1039/D0GC01521K

[50] Lima, R. B., Raza, R., Qin, H., Li, J., Lindström, M. E., Zhu, B. "Direct ligninfuel cell for power generation", Royal Society of Chemistry Advances, 2013, 3(15), pp. 5083-5089, 2013. https://doi.org/10.1039/c3ra23418e

[51] Dou, X., Li, W., Zhu, C. "Catalytic hydrotreatment of Kraft lignin into liquid fuels over porous $\mathrm{ZnCoO}_{x}$ nanoplates", Fuel, 283, Article number: 118801, 2021. https://doi.org/10.1016/j.fuel.2020.118801

[52] Klapiszewski, L., Szalaty, T. J., Jesionowski, T. "Depolymerization and Activation of Lignin: Current State of Knowledge and Perspectives", In: Poletto, M. (ed.) Lignin: Trends and Applications, IntechOpen, London, UK, 2018, pp. 1-27. https://doi.org/10.5772/intechopen.70376

[53] Wang, Z., Kang, H., Liu, H., Zhang, S., Xia, C., Wang, Z., Li, J. "Dual-Network Nanocross-linking Strategy to Improve Bulk Mechanical and Water-Resistant Adhesion Properties of Biobased Wood Adhesives", ACS Sustainable Chemistry and Engineering, 8(44), pp. 16430-16440, 2020.

https://doi.org/10.1021/acssuschemeng.0c04913

[54] Antov, P., Savov, V., Krišták, L., Réh, R., Mantanis, G. I. "Eco-Friendly, High-Density Fiberboards Bonded with UreaFormaldehyde and Ammonium Lignosulfonate", Polymers, 13(2), Article number: 220, 2021.

https://doi.org/10.3390/polym13020220

[55] Talabi, S. I., da Luz, A. P., Pandolfelli, V. C., Lima, V. H., Botaro, V. R., de Almeida Lucas, A. "Graphitization of LigninPhenol-Formaldehyde Resins", Materials Research, 23(2), Article number: e20190686, 2020.

https://doi.org/10.1590/1980-5373-MR-2019-0686
[56] Ponnuchamy, V., Gordobil, O., Diaz, R. H., Sandak, A., Sandak, J. "Fractionation of lignin using organic solvents: A combined experimental and theoretical study", International Journal of Biological Macromolecules, 168, pp. 792-805, 2021.

https://doi.org/10.1016/j.ijbiomac.2020.11.139

[57] Aracri, E., Blanco, C. D., Tzanov, T. "An enzymatic approach to develop a lignin-based adhesive for wool floor coverings", Green Chemistry, 16(5), pp. 2597-2603, 2014. https://doi.org/10.1039/c4gc00063c

[58] Ghorbani, M., Liebner, F., van Herwijnen, H. W. G., Pfungen, L., Krahofer, M., Budjav, E., Konnerth, J. "Lignin Phenol Formaldehyde Resoles: The Impact of Lignin Type on Adhesive Properties", BioResources, 11(3), pp. 6727-6741, 2016. https://doi.org/10.15376/biores.11.3.6727-6741

[59] Kalami, S., Arefmanesh, M., Master, E., Nejad, M. "Replacing $100 \%$ of phenol in phenolic adhesive formulations with lignin", Journal of Applied Polymer Science, 134(30), Article number: 45124, 2017. https://oi.org/10.1002/APP.45124

[60] Ammar, M., Mechi, N., Hidouri, A., Elaloui, E. "Fiberboards based on filled lignin resin and petiole fibers", Journal of the Indian Academy of Wood Science, 15(2), pp. 120-125, 2018. https://doi.org/10.1007/s13196-018-0216-3

[61] Gellerstedt, G. "Softwood kraft lignin: Raw material for the future", Industrial Crops and Products, 77, pp. 845-854, 2015. https://doi.org/10.1016/j.indcrop.2015.09.040

[62] Doosthoseini, K., Zarea-Hosseinabadi, H., Moradpour, P. "Low resin medium density fiberboard made from chemical activated hardwoods fibers", Journal of the Indian Academy of Wood Science, 7(1-2), pp. 36-42, 2010. https://doi.org/10.1007/s13196-011-0008-5

[63] Vineeth, S. K., Gadhave, R. V., Gadekar, P. T. "Chemical Modification of Nanocellulose in Wood Adhesive: Review", Open Journal of Polymer Chemistry, 9(4), pp. 86-99, 2019. https://doi.org/10.4236/ojpchem.2019.94008

[64] Karagiannidis, E., Markessini, C., Athanassiadou, E. "MicroFibrillated Cellulose in Adhesive Systems for the Production of Wood-Based Panels", Molecules, 25(20), Article number: 4846, 2020. https://doi.org/10.3390/molecules25204846

[65] Iglesias, M. C., McMichael, P. S., Asafu-Adjaye, O. A., Via, B. K., Peresin, M. S. "Interfacial interactions between urea formaldehyde and cellulose nanofibrils (CNFs) of varying chemical composition and their impact on particle boards manufacture (PBs)", Cellulose, Preprint under Review. https://doi.org/10.21203/rs.3.rs-315097/v1

[66] Kürschner, K., Hoffer, A. "Technologie und Chemie der Papierund Zellstoff-Fabrikation" (Technology and chemistry of paper and pulp production), Güntter-Staib, Biberach-Riss, Germany, 1929. (in German)

[67] Technical Association of the Pulp and Paper Industry "T 222 om-11 Acid-Insoluble Lignin in Wood and Pulp", Technical Association of the Pulp and Paper Industry, Peachtree Corners, GA, USA, 2011.

[68] Technical Association of the Pulp and Paper Industry "T 211 om-12 Ash in Wood, Pulp, Paper and Paperboard: Combustion at 525 Degrees C", Technical Association of the Pulp and Paper Industry, Peachtree Corners, GA, USA, 2012. 
[69] Tupciauskas, R., Gravitis, J., Abolins, J., Veveris, A., Andzs, M., Liitia, T., Tamminen, T. "Utilization of lignin powder for manufacturing self-binding HDF", Holzforschung, 71(7-8), pp. 555-561, 2017. https://doi.org/10.1515/hf-2016-0180

[70] Yotov, N., Savov, V., Valchev, I., Petrin, S., Karatotev, V. "Study on possibility for the utilization of technical, hydrolysis, lignin in composition of medium density fibreboard", Innovation in woodworking industry and engineering design, 6(2), pp. 69-74, 2017.

[71] Dumitrescu, L., Manciulea, I., Patachia, S., Perniu, D. "Wood Adhesives Based on Lignocellulosic Materials", In: Katalinic, B. (ed.) Annals of DAAAM for 2009 \& Proceedings of the 20th International DAAAM Symposium, Vienna, Austria, 2009, pp. $289-290$.

[72] Hoareau, W., Oliveira, F. B., Grelier, S., Siegmund, B., Frollini, E., Castellan, A. "Fiberboards Based on Sugarcane Bagasse Lignin and Fibers", Macromolecular Materials and Engineering, 291(7), pp. 829-839, 2006.

https://doi.org/10.1002/mame.200600004

[73] Pizzi, A., Papadopoulos, A. N., Policardi, F. "Wood Composites and Their Polymer Binders", Polymers, 12(5), Article number: 1115, 2020.

https://doi.org/10.3390/polym12051115

[74] Antov, P., Savov, V., Mantanis, G. I., Neykov, N. "Medium-density fibreboards bonded with phenol-formaldehyde resin and calcium lignosulfonate as an eco-friendly additive", Wood Material Science and Engineering, 16(1), pp. 42-48, 2021. https://doi.org/10.1080/17480272.2020.1751279

[75] Pizzi., A. "Wood Adhesives: Chemistry and Technology", CRC Press. Boca Raton, FL, USA, 1989. https://doi.org/10.1201/9780203733721

[76] Réh, R., Igaz, R., Krišták, L., Ružiak, I., Gajtanska, M., Božíková, M., Kučerka, M. "Functionality of Beech Bark in Adhesive Mixtures Used in Plywood and Its Effect on the Stability Associated with Material Systems", Materials, 12(8), Article number: 1298, 2019.

https://doi.org/10.3390/ma12081298

[77] Bekhta, P., Sedliačik, J., Bekhta, N. "Effects of Selected Parameters on the Bonding Quality and Temperature Evolution Inside Plywood During Pressing", Polimers, 12(5), Article number: 1035, 2020. https://doi.org/10.3390/POLYM12051035

[78] Westin, M., Simonson, R., Östman, B. "Kraft lignin wood fiberboards - The effect of kraft lignin addition to wood chips or board pulp prior to fiberboard production", Holz als Roh- und Werkstoffs, 58(6), pp. 393-400, 2001.

https://doi.org/10.1007/s001070050451
[79] Zhou, X., Tan, L., Zhang, W., Lv, C., Zheng, F., Zhang, R., Du, G., Tang., B., Liu, X. "Enzymatic hydrolysis lignin derived from corn stover as an intrinsic binder for bio-composites manufacture: Effect of fiber moisture content and pressing temperature on boards' properties", BioResources, 6(1), pp. 253-264, 2011. https://doi.org/10.15376/biores.6.1.253-264

[80] Theng, D., El Mansouri, N.-E., Arbat, G., Ngo, B., Delgado-Aguilar, M., Pèlach, M., À., Fullana-i-Palmer, P., Mutjé, P. "Fiberboards Made from Corn Stalk Thermomechanical Pulp and Kraft Lignin as a Green Adhesive", BioResurces, 12(2), pp. 2379-2393, 2017. https://doi.org/10.15376/biores.12.2.2379-2393

[81] Lee, T. C., Mohd Pu'ad, N. A. S., Selimin, M. A., Manap, N., Abdullah, H. Z., Idris, M. I. "An overview on development of environmental friendly medium density fibreboard", MaterialsToday: proceedings, 29(1), pp. 52-57. http://doi.org/10.1016/j.matpr.2020.05.679

[82] Bouajila, J., Limare, A., Joly, C., Dole, P. "Lignin plasticization to improve binderless fiberboard mechanical properties", Polymer Engineering and Science, 45(6), pp. 809-816, 2005. https://doi.org/10.1002/pen.20342

[83] European Committee for Standardization "EN 310:1993 Woodbased panels. Determination of modulus of elasticity in bending and of bending strength", CEN, Brussels, Belgium, 1993.

[84] European Committee for Standardization "EN 317:1993 Particleboards and fibreboards - Determination of swelling in thickness after immersion in water", European Committee for Standardization, Brussels, Belgium, 1993.

[85] European Committee for Standardization "EN 323:2001 Woodbased panels - Determination of density", European Committee for Standardization, Brussels, Belgium, 2001.

[86] European Committee for Standardization "EN 622-5:2010 Fibreboards - Specifications - Part 5: Requirements for dry process boards (MDF)", European Committee for Standardization, Brussels, Belgium, 2010.

[87] Nasir, M., Gupta, A., Beg, M. D. H., Chua, G. K., Kumar, A. "Physical and mechanical properties of medium density fiberboard using soy-lignin adhesives", Journal of Tropical Forest Science, 26(1), pp. 41-49, 2014. 